\title{
The Power of Reflective Writing for Early Childhood Teachers in Palestine
}

\author{
Buad Kahles ${ }^{1, *}$ \\ ${ }^{1}$ Department of Elementary and Kindergarten, Al-Quds University, Jerusalem, Palestine \\ *Correspondence: Department of Elementary and Kindergarten, Al-Quds University, Jerusalem, Palestine. E-mail: \\ buad33@gmail.com
}

Received: December 22, 2014

Accepted: January 19, $2015 \quad$ Online Published: February 2, 2015

doi:10.5430/wje.v5n1p94

URL: http://dx.doi.org/10.5430/wje.v5n1p94

\begin{abstract}
This research aimed to highlight the power of reflective writing for early childhood teachers in Palestine, seven teachers in Palestine participated in this qualitative study, they were asked to write their reflections for 18 months. Data was gathered using semi-structured interviews and reflective writing journals. Data was analyzed using thematic analysis approach in order to determine the possible effects of using reflective writing with teachers on developing their reflective thinking. The results of the study indicated that reflective writing was capable of developing teachers' reflective thinking and helped them to change their attitudes toward themselves and empower them as well.
\end{abstract}

Keywords: reflective teaching; empowerment; reflective writing

\section{Early Childhood Education in Palestine (ECD)}

In the past few years there have been some strides towards improving the early childhood development sector in the West Bank and Gaza. Preschools in the West Bank and Gaza are usually staffed by young, inexperienced teachers with only a secondary education and little awareness of effective ECD teaching and learning practices. Many preschool teachers end up in the education sector because they do not believe there are alternative job opportunities, or because they simply need a salary to sustain their lives. Still low salaries and low status mean teaching is not an attractive profession, hence leading to a high teacher-turnover rate. Few professional development opportunities exist for individuals who want to become specialized in preschool education and in in-service training, which means that most teachers continue using poor pedagogical methods.

To overcome the challenges and problems faced by the Palestinian Ministries of Education and Higher Education. The Universities, Palestinian NGOs, society and UNISEF are working together towards developing a strategic plan. The strategy seeks to develop policies, programs, and activate laws related to children and early childhood aspiring to ensure the rights, needs and wellbeing of the Palestinian child as an integrated developmental unit. It also seeks to provide policies and laws that can help improve the services and resources available for learning (including health and social services) that respond to the children's needs to ensure they have a comprehensive and integrated development in a quiet, decent and appropriate life.

\section{Introduction}

The need for conducting a study about reflective thinking arose from a serious concern about the actual quality of teaching in the kindergartens at the Palestinian Territories. A report issued by the Palestinian Ministry of Education in 2006 indicated an urgent need for improving early childhood education. It also indicated an immediate need for creating new training programs addressing kindergarten (KG) teachers. It was assumed that by fulfilling the KG teachers' needs, they will be able to enhance their professional capacities when working with pre-school children and accordingly provide the children all the respect and appreciation they deserve. Reflective teaching helps teachers to be aware of themselves and of their teaching.

The study on reflective teaching is much greatly indebted to the writings of John Dewey, Dewey was the first 
researcher to point out the significance of reflection and its importance in research. In his seminal work "How We Think?" Dewey 1930 established the basics on reflection, and set the ground on reflective thinking, According to him, reflective teaching helps teachers develop their sense of professional responsibility. The characteristics of reflective thinking as an approach was based on Dewey's methodology in investigating the facts that lead to finding solutions to problems occupying much of the teachers' time and thinking. He investigated the reasons behind the failure or success of lessons. Such approach primarily depends on determining a particular cognitive theory that the teacher adopts with regard to children's capacities to learn. In order to do so the teachers involved must have to consciously engage in reflection as it allows them to analyze their theoretical knowledge and intellectual perspectives about the learning of children? (Dewey, 1930)

Dewey helped open new horizons for researchers to examine the different aspects of reflective thinking. Educators, such as Jerome and Algarra (2005) have reiterated the need for teachers to use reflection in their work. Reflective thinking motivates teachers to review their practices. It is from this standpoint that one can be certain that reflective thinking enables the teacher to have a better perception of himself/herself and of the roles that (s)he might be called upon to assume. Reflective teaching involves a closer look at one's self, a deeper thinking and contemplation that hopefully will culminate in a change in his/her practices.

However, certain questions about the practicality of reflection surfaced. Such questions include the following: First: Is reflection possible to practice? How difficult or easy is it to do reflection? Is there enough time for it to be implemented on the job? Is it necessary for teachers? What impact does reflection have on teaching? What types of discussions are needed to evoke reflection?

Reflection is a meaning-making process that takes the learner from one experience to the next, but with a deeper understanding of its relationships and connections to other experiences and ideas. It is the thread that makes continuity of learning possible, and ensures the progress of individuals and ultimately the society.

Rodrgers (2002) believes that teachers should be capable of thinking systematically about their practices. This usually requires a lot of courage to criticize their own practices, and to listen to the advice of their fellow teachers or supervisors. It also requires making use of the findings of the latest research in reflective thinking.

In order to overcome some of the problems that a teacher might experience during reflection, and to help her/ him in recording her/ his reflections, it is important to look for someone who can guide the teacher in her/ his work and show her/ him how to reflect about her/ his thoughts and practices and to critique them frankly and objectively without feeling pressured or threatened. Several workshops are therefore needed to train teachers in reflective thinking. These workshops must be conducted in a setting of security and tolerance, allowing the participating teachers to express their individual fears, feelings, preferences, interests and attitudes freely. Participants should also be given the time to record their thoughts in a reflective journal or diary (Reed, 2002).

However reflection is a systematic, rigorous, disciplined way of thinking, with linked to roots to scientific inquiry. Reflection needs to happen in the community, in interacting with others. Reflection requires attitudes that value the personal and intellectual growth of a person and others.

Reflective teaching means looking at what you do in the classroom, think about why you do it, and if it works - a process of self-observation and self-evaluation, and by collecting information about what goes on in classrooms, then analyzing and evaluating the collected information. By that we identify and explore our own practices and its underlying beliefs. Then, this may then lead to create change and improvement in our teaching practices.

Lee (2005) advocated the effectiveness of early childhood programs growth using reflective thinking. However, other researchers indicated that teacher education programs are not preparing teachers adequately to educate future generations of students. As a reaction to this, reflective teacher education has been investigated as an alternative approach to initial teacher preparation and professional development.

The central goals of reflective teacher education are to develop teachers' reasoning about why they employ certain instructional strategies and how they can improve their instruction to achieve positive effect on students. Therefore, it is recommended that pre-service teachers engage in reflective activities not only to better learn new ideas, but also to sustain professional growth after completing the program. (Lee, 2005).

Reflection is a conscious, active process of focused and structured thinking which is distinct from free floating thoughts, as in general thinking or day-dreaming. How our thoughts are generated is still an important research question in cognitive science. During reflection the relevant thoughts may be generated per se by the reflective process or reflection may be a process of selecting relevant thoughts that are spontaneously generated (Gelter, 2003). 
Reflective thinking helps teachers review their thoughts and believes in a "platform" where ideas, attitudes, perspectives, and perception are revealed. In these platforms, teachers confront their thoughts and believes that usually affect their instructional and classroom practices. Through these dialogic platforms and through reflective journals or diaries, teachers' voices are heard and reviewed to the extent that leads to their professional development. Traditionally teachers' voices were low and not heard but in these days we need to dialogue teachers in a way that helps them express their feelings, believes and attitudes in order to sow the seeds of trust. (Khales, 2010).

Through teachers' empowerment, teachers feel more responsible, and having more control and meaning on their practices. This helps in motivating teachers and leads them to be independen as they carry the responsibility of their own development. (Khales,2010).

The role of reflection and inquiry - ideas largely coming from "Western" educational research and thinking show tremendous potential as a foundational vehicle for educational change. Palestinian teacher educators, student teachers, and head teachers will now have to move forward to create their own, homegrown versions of the particular forms and functions of inquiry and reflection that make sense and benefit their particular contexts ( Khales \& Meier, 2013).

Reflection and reflective writing are not new terms in the field of teacher education. Reflective practices on teaching were used as a strategy on development for many years, and have been described in different ways. Writing is a technique used in teacher education programs to encourage PSTs make connections between what they learnt on campus-based courses and their practical experiences, thus enhancing their reflective abilities (Yost et al, 2000).

A learning journal is 'essentially a vehicle for reflection and is 'an accumulation of material that is mainly based on the writer's processes of reflection. Given the many benefits of learning journals, it is not surprising that they have been employed in a diverse array of disciplines to promote students' capacity for reflection, critical thinking and, ultimately, their broader learning (Bell et al, 2011).

(Yessilbursa, 2011) contributes to the knowledge base on reflective writing of non-native pre-service English Language teachers and emphasizes the importance of tapping into their reflections early on in pre-service teacher education.

Teachers face some challenges in writing their diaries as they have to be vulnerable to their own practices and this might cause a threat especially to novice teachers. These reflective writing help teachers critically criticize themselves to help them better understand themselves. And, whether diaries are written on a daily or weekly basis, they provide teachers with opportunities to inquire their thoughts, to break the restrictions imposed on them by the daily chore, thus their reflective journals or diaries help them improve their practices, their thoughts and their feelings (khales, 2010).

\section{Research Problem}

Early childhood teachers in Palestine teach children without practicing reflection and self evaluation of their work, because of their overloaded working environments and overcrowded classrooms. The learning environments in kindergartens don't encourage teachers to reflect and write reflective journals. Teachers need to change their beliefs towards reflection and reflective writing because they don't like to show their weakness through written reflections; they like to blame other elements in the education process for their weaknesses. Aditionally, teachers are not requested to write reflections because of the lack of support, encouragement and appreciation of leaders or supervisors. Upon what was stated earlier reflective writing and reflection are important methods used to encourage teachers understand themselves, their roles and to overcome the challenges and difficulties they might face with no threat or fear, and with a sense of confidence and satisfaction.

\section{The Purpose of the Study}

This study sought to investigate the power of reflective writing for early childhood teachers in Palestine, and to help teachers become aware of their thinking, reflect analytically and critically on their work in order to improve children's learning by providing teachers with the oopportunity to revise their practices through reflective writing and reflective dialogue. 


\section{Research Questions}
A. How reflective writing develops early childhood teachers' reflective thinking?
B. What are the teachers' experiences in reflective writing?
C. What is the power of reflective writing?
D. What is the teacher's perspective toward reflective writing?

\section{Research Methodology}

To achieve the aim of the study qualitative research was employed using casestudy based results. Case study refers to a systematic and methodological way of collecting data about a specific case, it can be a person, institution, class, group, etc. Data is collected in natural situations. The opinions of the participants are usually gathered and taken into consideration. Accordingly, seven teachers in one of the kindergartens in Jerusalem participated in this study, were interviewed and their reflective journals were analyzed.

\subsection{Kindergartens Setting}

This study was conducted in two kindergartens in Jerusalem. I chose eight teachers in two kindergartens who agreed to participate willingly in the study. The kindergartens enroll children aged 3-5 years, the number of children in each classroom is around thirty (30) children, each kindergarten has five classes. The kindergartens' environments are designed to keep track of active learning and a holistic integrative learning system, the kindergarten include classrooms with activity centers and playgrounds. The children learn languages, science, math, art, drama, music and religion. The teachers got trainings in teaching methods, active learning, and drama. Teachers did not take any training on reflective thinking, therefore the teachers explained that they do not know what reflection means, and that they were never asked to write reflections.

\subsection{Participants}

Seven teachers from one of the kindergartens in Jerusalem participated in this study. Those teachers teach 4-5 year old children. Their teaching experiences range from 8 to 14 years. All seven teachers hold a bachelor's degree in Early Childhood Education (ECE).

Table 1. Informational Data about the Seven Teachers Who Participated in the Study

\begin{tabular}{|c|c|c|c|}
\hline Teacher's Name & $\begin{array}{l}\text { Years of Teaching } \\
\text { Experience }\end{array}$ & Certification & $\begin{array}{l}\text { Children's age and } \\
\text { Class size }\end{array}$ \\
\hline A & 14 years & $\begin{array}{l}\text { B. A. in Early Childhood } \\
\text { Education }\end{array}$ & $\begin{array}{l}4 \text { years } \\
30 \text { children }\end{array}$ \\
\hline B & 8 years & $\begin{array}{l}\text { B. A. in Early Childhood } \\
\text { Education }\end{array}$ & $\begin{array}{l}5 \text { years } \\
32 \text { children }\end{array}$ \\
\hline $\mathrm{C}$ & 14 years & $\begin{array}{l}\text { B. A. in Early Childhood } \\
\text { Education }\end{array}$ & $\begin{array}{l}5 \text { years } \\
33 \text { children }\end{array}$ \\
\hline $\mathrm{D}$ & 8 & $\begin{array}{l}\text { B. A. in Early Childhood } \\
\text { Education }\end{array}$ & $\begin{array}{l}5 \text { years } \\
28 \text { children }\end{array}$ \\
\hline E & 10 & $\begin{array}{l}\text { B. A. in Early Childhood } \\
\text { Education }\end{array}$ & $\begin{array}{l}5 \text { Years } \\
30 \text { Children }\end{array}$ \\
\hline$F$ & 9 & $\begin{array}{l}\text { B. A. in Early Childhood } \\
\text { Education }\end{array}$ & $\begin{array}{l}5 \text { Years } \\
28 \text { children }\end{array}$ \\
\hline G & 9 & $\begin{array}{l}\text { B. A. in Early Childhood } \\
\text { Education }\end{array}$ & $\begin{array}{l}4 \text { years } \\
30 \text { children }\end{array}$ \\
\hline
\end{tabular}

\section{Results}

This research aimed to investigate the power of reflective writing for early childhood teachers in Palestine to help the teachers become more aware of their thinking, reflect analytically and critically on their work and support them to improve their teaching instruction by giving them to opportunity to revise their practices through reflective writing and reflective dialogue. In order to answer the research questions, data was collected using different sources. This section will discuss the results of the investigation; analyze meanings of answers received in the research using the following themes: 


\subsection{Developing Reflective Thinking via Reflective Writing}

Teacher/participant (1) in this study expressed meanings brilliantly in her reflective journal and in one of the discussion groups conducted about reflective thinking by saying:

"From this experience I learned to reflect and "judge myself", not only when I do something wrong, but in all situations. I would then ask myself why did I behave like that, and how was I supposed to behave, hence improve my behavior. I learned to reflect on every move I make, my interaction with others, even my appearance and looks while interviewed - not only with the children, but also with older people like my colleagues at work or my family at home. I also started noticing every move I make- how I touch my children, patt them or even look at them. Perhaps I wasn't paying attention that I was mostly nervous, but the way I look at the children would tell them that I was in fact nervous. Therefore I started to pay more attention to myself. I also started to pay more attention to the tone of my voice. Sometimes I would forget myself and raise my voice again. (Reflective Journals)

Reflection opened up new horizons for teacher (1) by which she discovered her competencies and creativity. Reflection, for instance, led her to look for new ways of dealing with children, and for new ways to help her when teaching children.

The analysis of teacher (2) reflective writing and interviews showed that the experience helped her undergo great changes. The teacher reflective writing motivated her to think deeply and regularly rather than occasionally when faced with difficulties regarding her children. Reflection for her became a necessity; she described her behavior by saying: "I couldn't live" without it. The reflective writing also made her look for real meanings in reflection, which she had not heard of before taking the training program. Through reflection she was able to identify her weaknesses and strengths and to change her style of thinking even with regard to her own children at home. She used to think that the best mother is one who controls her children and makes them do whatever she would ask them to do.

Teacher (3) showed beyond doubt that reflective thinking increased her self-confidence. Previously, she had never appreciated her talents and capabilities, and was mostly afraid to express herself in public or to talk and express herself in front of other people. Later she discovered that she had an excellent talent for leading discussion groups; this boosted her self-confidence, and helped her develop herself and her confidence more and more.

I started to engage in reflection a lot and began to understand the real meaning of reflection. I had once heard of this term but didn't know what it means. I used to think things over only when I had a problem with the children and only then would judge myself and why I had behaved with them that way. (Reflection Journal)

Reflection made me understand myself more, and understand what I want. For this reason I stopped quarreling with my husband and my kids at home. My nervousness (irritability) with them had decreased immensely; I used to control them, but now I started to realize they were poor fellows. (Discussion Group)

Reflection was a very good chance for me to change because it increased myself-confidence. I used to escape from facing people in big discussions, even when I knew that I had a lot to say which others could benefit from, but I used to be afraid to say these things because I wasn't confident in myself. Now I have proven to myself practically that I have confidence. In the summer vacation I talked to mothers in the summer camp about how they can deal with spare time. It was a very good experience for me. (Interview)

Teacher (4) rushed towards reflection and was convinced that reflection represented a great challenge to her and it moved her deeply. It made her see things she had never noticed before, most noticeably, the significance of engaging in reflection in her own work and in reviewing her own self. More importantly, the training program broke the ice between her and the others and so she started to communicate with them with clear ease, particularly with her own daughters. Before, she had great difficulty dealing with her daughters as they were at that stage in life when they needed her full understanding and attention. Her ability to engage in reflective thinking guided her to dialogue with them, with herself and with others. Training in reflective thinking motivated teacher (3) to shift her lifestyle.

Generally speaking, I started reflecting about everything I do and judge myself about my actions throughout the whole day. The training program taught me to stop and think with myself. Now after every action I do, I think it over and decide whether it was appropriate or not. In this respect, there were so many questions going inside my head and I tried to change as much as I could. In fact I started thinking about changing so many things for the upcoming year. (Interview) 
Reflection helped teacher (5) develop her personality, which showed most remarkably in recognizing her potential abilities and in understanding her future role in light of her new perspectives toward children's learning which arises from the notion that the learning process is one of interaction between the teacher and her children as well as among the children themselves.

I'm trying to find my own capabilities, I'm gathering information about the previous years, and I'm trying to change for next year (God willing!) by becoming more vigorous and entrusted. (Interview)

Reflective writing increased teacher (5) sense of responsibility towards her work and her children. Reflective thinking opened wide horizons for her to review her work. She now considers reflection as a conscience raiser and a motivator to monitor herself.

Teacher (6) with her great appreciation of the training program, its significance and of her own enthusiasm to reflective thinking made her recommend that everybody should be attend the reflective thinking training, including $\mathrm{KG}$ headmasters and headmistresses.

I wish a workshop could be held for teachers of other KGs. I also wish if such a program would be offered to schools and KG headmasters and headmistresses. (Discussion Group)

It was not easy for teacher (7) the seventh teacher participating in the training program, to become accustomed to reflection or to talk about reflection as she had never heard of this concept before. After the writing reflections and discussions conducted on reflection it became indispensable for her. The experience pushed her to reflect about every situation she went through, negative or positive.

I had never heard of the term "reflection" before, but after I was introduced to it, I discovered that a teacher has to reflect a lot, not only when she faces a problem but at all times. Perhaps she needs to reflect more about the positive situations which she experiences as much as the negative. (Reflection Journal)

In this context, teacher (7) views reflection as a gate which allows a person to get into his/her inner self. She regrets past times when she did not run over her actions with the children, especially those times when the teacher really needed to reflect to be able to solve problems that she encounters at her work environment.

Oh God! How important reflection is, especially since we don't know why certain things are happening to us. I feel regretful when I do something with the children and then I think it over and wish I had thought of it differently and better, especially when I promise a child to do something, then not to do it. (Interview)

In addition, the reflective writing helped her become more engaged in reflective teaching and to use inner dialogue with herself to overcome certain psychological problems she had been suffering from. This teacher was a clear example that showed how reflective writing could treat a person psychologically by bringing out psychosocial aspects which are hidden inside her and which she was afraid to face or talk about with anyone else due to her wrong beliefs that this could harm her. Therefore, she suggested that everybody should be trained on reflective teaching as it would eliminate the need to see a psychological consultant.

Reflective thinking is a special thing. The training program made me bring out things from my inner self which I had always feared to bring out, and that was a great psychological relief.

\subsection{The Power of Reflective Writing and Teachers' Experiences}

Keeping a reflective diary was not an easy task for teachers. Each teacher talked about the difficulties she had faced while recording her diaries, and the apprehensions she had when they were asked to keep a reflective diaries. Recording one's reflections constituted a proof of the teacher's experiences, their points of views and feelings. After all, the diaries were written by the teachers themselves about themselves and that represented a self-disclosure. An additional difficulty that surfaced was the fact that keeping a diary required certain writing skills and some competencies in expressive writing.

Teacher (1) described her experience with writing a daily or a weekly journal as a very difficult task. At first, it was not easy for her to write about herself honestly and to disclose everything about herself. Yet she was soon able to overcome her difficulty and started to write about her feelings and thoughts strongly and comfortably. She discovered later that expressing her feelings and thoughts in a reflective diary helped her monitor herself in a much better way.

I had never written about myself and my feelings, and when I wrote for the first time I had difficulties in writing. Now, thanks to God I can write my reflections and judge myself better. 
Teacher (2) showed how the training program helped her write her reflections, which at first had been difficult to do so. Writing her reflections increased her ability to express her feelings, which in turn reflected positively on her family's life with her kids and husband.

I admit that the most important thing I got out of writing a reflective diary was that things started to become better at home with the own kids. I started to talk about my feelings with my kids - something I had never done before. Now I also started to ask them to talk about their feelings and this made me feel comfortable. When we were brought up, there was no room for us to express our feelings, but now I feel the opposite.

Teacher 3 admits that writing her reflections was a very difficult task at first, and it took her a long time to select the appropriate phrases to express what was going inside her mind: thoughts, worries, anxieties and concerns. Thanks to her persistence and repeated attempts to write, she was able to select the most appropriate phrases to express her feelings and thoughts and aspirations as well.

When I began to write my reflections, a lot of thoughts started to come out, but I couldn't write. Writing was difficult for me. The first time we were asked to write our reflections, I was very upset and hesitant for a moment. It was not clear to me what to write, and then I tried and luckily was able to write. Keeping my weekly journal in my class and the preparation notebook helped me to write. Still it is not easy; it is tiresome; but it makes me see where I am. (Reflective Journal)

Teacher (5) on the other hand, considers writing reflective journals one of the most difficult tasks as it requires a lot of effort in selecting phrases to express herself. Yet, she saw the advantage of writing reflections in helping the teacher to better understand herself and to do so more deeply.

The most difficult thing for a person is to write about himself/herself, especially for a $K G$ teacher, who would not know what to write. Writing helps a lot.

Teacher (6) also encountered a lot of difficulties when writing reflective journals because she was afraid to reveal herself honestly and to disclose her convictions and thoughts. This apprehension made her raise several questions in an attempt to evade writing her reflections.

Why reflection diary? What can I write? write about what? Let's not write. (Group Discussion)

Teachers 7 it was not long enough before she started writing her reflections, though she continued to talk about the difficulties of the task despite her admission on the importance of reflective writing for $\mathrm{KG}$ teachers.

In the first reflections, I wondered about what to write and about what the researcher wanted from us. I faced the fear of writing. Then I began to see writing as positive feedback because there are things that do not come easily to my mind. Reflective writing is really difficult.

\subsection{Teachers Views on Reflective Writing}

Reflective writing provides teachers with the opportunity to be aware of themselves, and develop a range of skills, either explicitly or implicitly. The following list is of what teachers said about the power of reflective writing.

Table 2. Teachers Views on Reflective Writing

\begin{tabular}{lll}
\hline Item & $\begin{array}{l}\text { Number of } \\
\text { teachers }\end{array}$ & $\begin{array}{l}\text { percent } \\
\text { age }\end{array}$ \\
\hline $\begin{array}{l}\text { Reflective writing as a tool for professional development. } \\
\text { Reflective writing provides us with many chances to think critically. }\end{array}$ & 5 & $9 \%$ \\
$\begin{array}{l}\text { Reflective writing leads conversations. We can learn a great deal about } \\
\text { others' perspectives, and alternative explanations of events. }\end{array}$ & 7 & $6 \%$ \\
$\begin{array}{l}\text { Reflective writing is like magic to teachers it helps them become open } \\
\text { minded and think deeply. }\end{array}$ & 4 & $13 \%$ \\
$\begin{array}{l}\text { Reflective writing helps the leaders and decision-makers } \\
\text { Reflective writing affects teachers' beliefs with regard to teaching. }\end{array}$ & 6 & $7 \%$ \\
$\begin{array}{l}\text { Reflective writing encourages teachers to be researchers. } \\
\text { Reflective writing helps us to better understand our selves }\end{array}$ & 3 & $11 \%$ \\
Reflective writing helps teachers understand the meaning of teaching. & 6 & $6 \%$ \\
Reflective writing helps teachers face problems & 7 & $11 \%$ \\
& 6 & $13 \%$ \\
\hline
\end{tabular}


Thirteen percent of teachers reported that reflective writing affects their' beliefs with regard to scrutinizing their teaching while eleven percent of teachers believed that reflective writing helps them take better decisions as a result of reflection. Reflection also helped teachers face problems and helped them understand themselves better. Nine percent of teachers believed that reflective writing is a tool for professional development. However, seven percent of teachers think that reflective writing helped them become open-minded and think more deeply. Six teachers revealed that reflective writing encouraged them to be researchers as well as providing them with many chances to think critically.

\section{Conclusion}

The findings of the study showed that writing journals motivated teachers' engagement in reflective thinking. It helped each of them to acquire greater awareness about themselves and about what they are doing. Self judgment was used by teachers as an indication that reflection became a constant companion of teachers all times when implementing their programs. Each teacher expressed in her own way her journey with reflective thinking over duration of 18 months. The use of reflective writing by the teachers indicated the extent to which their experiences with reflective thinking had on them: not only in their work with children, but also in their own lives. Reflective writing seems to bring out what is inside them. Among other things, reflective thinking helped them discover their strengths and weaknesses. An internal, continuous daily self-dialogue was initiated within them, leading to a feeling of tranquility and self-assurance after a period of great pressure, anxiety, severe tension and self-dissatisfaction. Reflective writing provided them with a golden opportunity to know their inner selves and to realize their aspirations in life. Reflective writing opened up wide horizons for each of them. Reflective thinking was not exclusively associated with a certain problem on a given day; it became part of everything that the teachers experienced or did. They engaged in reflective thinking before, during and after undertaking any action.

\section{References}

Dewey, J. (1933). How We Think: A Restatement of the Relation of Reflective Thinking to the Educative Process. Lexighton, Massachusetts, DC Health.

Gelter, H. (2003). Why is reflective thinking uncommon. Reflective Practice, 4(3), 337-344. http://dx.doi.org/10.1080/1462394032000112237

Jerome, L., \& Algarra, B. (2005). Debating: a reflection on the place of debate within secondary school. The Curriculum Journal, 16(4), 493-508. http://dx.doi.org/10.1080/09585170500384610

Khales . B., \& Meir, D. ( 2013). Toward a New Way of Learning - Promoting Inquiry and Reflection in Palestinian Early Childhood Teacher Education. The New Educator, 9(4), 287-303. http://dx.doi.org/10.1080/1547688X.2013.841504

Khales, B. (2010). Reflective Thinking missing in curriculum and instruction. Chapter in Book "Reading in Curriculum and instruction": (Harb, M). Dar Wael ,Publication, Jordan.

Lee, H. (2005). Understanding and assessing preserves teacher reflective thinking. Teaching and Teacher Education, 21(6), 699-751. http://dx.doi.org/10.1016/j.tate.2005.05.007

Ministry of education and Higher Education, Palestine. (2008). Education Development Strategic Plan 2008-2012 Towards Quality Education for Development.

Reed, Y. (2002). Investigating teachers take up reflective practice from an in service professional development teacher education program in south Africa. Educational Action Research, 10(2) 252-274. http://dx.doi.org/10.1080/09650790200200185

Rodrgers, G. (2002). Defining reflection: Another look at John Dewey and reflective thinking. Teachers College Record, 10(4) 842-866. http://dx.doi.org/10.1111/1467-9620.00181

Yessilbursa, A. (2011). Reflection at the Interface of Theory and Practice: an Analysis of Pre- Service English Language Teachers' Written Reflections. Australian Journal of Teacher Education, 36(3), 104-116. http://dx.doi.org/10.14221/ajte.2011v36n3.5

Yost, D. S., Sentner, S. M., \& Forlenza-Bailey, A. (2000). An examination of the construct of critical reflection: Implications for teacher education programming in the 21st century. Journal of Teacher Education, 51(1), 39-49. http://dx.doi.org/10.1177/002248710005100105 